\title{
Prostitution: The Enconomics Of Sex And Power Dynamics In El Saadawi’SWoman At Point Zero, Adimora-Ezeigbo'STrafficked And Unigwe’S On Black Sisters Street
}

\author{
Oyeh O. Otu ${ }^{1, *}$ \\ ${ }^{1}$ Department of English Studies, University of Port Harcourt, East-West Road, Port Harcourt, Nigeria \\ *Correspondence: Department of English Studies, University of Port Harcourt, East-West Road, Choba, P.M.B. \\ 5323, Port Harcourt, Nigeria. Tel: 234-703-419-4922. E-mail: ichieoyeh@yahoo.com
}

Received: December 14, 2016

Accepted: December 19, 2016

Online Published: December 27, 2016

doi:10.5430/wjel.v6n4p8

URL: http://dx.doi.org/10.5430/wjel.v6n4p8

\begin{abstract}
Many feminist writers and critics have projected female prostitution as a radical and aggressive strategy aimed at undermining patriarchal values and wresting power and subjectivity from men. Many have argued that through prostitution women revolt against the traditional double standards which on one hand grant men license to be sexually adventurous, promiscuous and unfaithful to their partners, and on the other hand legislate and enforce grave moral and social sanctions against women who engage in the same acts. Such critics aver that women move from the position of passive sex objects designed for men's sexual pleasures to the position of agency and subjectivity that enable them express their sexuality, and more importantly use their bodies to turn men to objects of sexual and economic exploitation. But this paper argues that sex is a huge industry ultimately controlled by men. The three African novels studied here reveal that from sex tourism, ownership and management of hotels and brothels, to the mafia-like transnational business of trafficking in women, men control the sex industry, and that prostitution, by objectifying and commodifying the woman's body, makes women (female prostitutes to be specific) objects of sexual and economic exploitation and victims of modern day slavery.
\end{abstract}

Keywords: prostitution; the economics of sex; female sexuality; the sex industry; female powerlessness; sexual slavery; trafficking

\section{Introduction}

In her report to the United Nations Commission on Human Rights, Huda (2006, n.p.) avers that:

The act of prostitution by definition joins together two forms of social power (sex and money) in one interaction. In both realms (sexuality and economics) men hold substantial and systematic power over women. In prostitution, those power(s) disparities merge in an act which both assigns and reaffirms the dominant social status of men over the subordinated social status of women.

One of the reasons for female prostitution is female powerlessness: socio-politically and economically. Men control sex (including the woman's body and sexuality) and the economy. More often than not women take to prostitution due to lack of access to opportunities, and opportunities are gateways of self-actualization and economic empowerment without which they are vulnerable to men who demand sex in exchange for money or any other assistance they may need. Besides, in Africa women have always been seen as their parents' or family's or community's wealth which in plain language translates to the woman being an object of beauty or sex, a commodity, a chattel. Some African scholars have made presentations about the enormous power and prestigious status of women in Africa. The views of Chinweizu -(1990) in Anatomy of Female Power are representative. According to him, women rule men, and with their sovereign power over men they rule the world. Accordingly, he argues that patriarchy is a façade. This female power, in his view, derives mainly from the woman's body which in Nigerian parlance is called "bottom power". But such arguments present a partial truth, somewhat romantic and Utopian. Such studies usually focus on few women whose positions and experiences do not affect the condition of ninety-nine percent of women in their societies. 
Some views about African women are not based on historical facts. For instance, Diop (1987) declaims, "Thanks to the matriarchal system, our ancestors prior to any foreign influence had given women a choice-place. They saw her not as a sex object but a mother" (p. 33). Whatever the merit of this argument may be, the fact remains that motherhood on its own does not translate to economic empowerment, dignity and high social status. Right from precolonial times, women have been treated as objects of pleasure, and female sexuality has been commodified and sold by various means, including the sale of a woman to the highest bidder in the name of bride price. As Dworkin (1995) aptly puts it, "Most social arrangements for the exchange of women operate on one ancient model or the other: stealing, which is rape; or buying and selling, which is prostitution" (p. 239).

\section{Sex, Economics, and Power in the Selected Texts}

Saadawi- (2007) portrays domestic prostitution in Woman at Point Zero, but Adimora-Ezeigbo and Unigwe depict international/transcontinental prostitution inTrafficked and On Black Sisters Street respectively.

Woman at Point Zero is set in Egypt, an Islamic society. In this novel, Saadawi narrates, analysizes and questions the complicity of not just individuals and families but also religious and political institutions in the subjugation, objectification and commodification of women in the Arab world. Firdaus, the heroine of the novel, is a brilliant young woman destroyed by obnoxious sexist socio-cultural practices, backed or permitted by both Islamic religion and the state (the law) in Egypt. After losing both parents, she is taken to Cairo by her uncle who used to abuse her sexually while she was still a child. She is curious, intelligent and discerning, as a child. "Sometimes I imagined that I would become a doctor or an engineer, or a lawyer, or a judge” (p. 24), she says. Unfortunately, she does not become any of these because after her secondary school education, her uncle, a Sheikh and man of religion, and his bitter wife ruin her life by selling her to Sheikh Mohmound in the name of marriage.

Whereas she is yet to turn nineteen, Sheikh Mahmoud is over sixty, and is sick and disgusting. "On his chin, below the lip, was a large swelling, with a hole in the middle. Some days the hole would be dry, but on others it would turn into a rusty old tap exuding drops red in colour like blood, or whitish yellow, like pus” (p. 45). Partly because she wants Firdaus out of her house and partly because of money, Firdaus's uncle's wife who happens to be a relative of Sheikh Mahmoud (a sick widower and pensioner) talks her husband into giving Firdaus to Sheikh Mahmoud in marriage in exchange for money:

'If I speak to him I am sure he will agree. I intend to ask him for a big dowry'

'How much?'

'A hundred pounds, or perhaps even two hundred if he has the money' $\quad$....

'If he accepts to pay one hundred pounds that will be sufficient blessing from Allah. I will be able to pay debts and buy some underwear....' (pp. 38-39).

Like a commodity, Firdaus is sold into bondage in the name of marriage. She is mistreated, her body violated physically and sexually, and her honour and dignity trampled upon. This type of dehumanizing abuse in marriage is traceable to the commodification of women. To some people, especially those who think that patriarchal practices are natural and immutable, the payment of bride price or dowry makes for law and order and confers honour on marriage. But this practice has been abused by parents or guardians who see their daughters or wards as chattel and husbands who treat their wives as mere property, to be used and abused. A classic example of how marriage reduces women to sex objects and prostitutes is the practice of Nikah al-Nut'ahor mut'ain Islamic law. This is the concept of temporary marriage for enjoyment and women who participate in this are called musta'jara or "rented women". "Mut'a is considered a kind of 'rented' because in general a man's basic aim in this kind of marriage is the sexual enjoyment of a woman, and in return for his enjoyment the woman receives a certain amount of money or property" ("The Four Pillars", n.p.).According to Saadawi (1980) in The Hidden Face of Eve:

In its essence real honour is in contradiction with all forms of slavery, subjugation and imposition, and with all forms of trade and commercialization of human beings, whether they be slaves, women, or children. True honour is fundamentally against transforming a human being into an instrument or an object, or a commodity for sale. The marriage customs and laws followed in our patriarchal and class society are the negation of true honour, for they have transformed women into merchandise, which can be bought in exchange for a dowry and sold at the price of an alimony (p. 51).

It is in the course of running away from this terrible marriage that Firdaus is taken in by Bayoumi who later turns her into a sex slave and later brings his friend to join him in violating her. She escapes from Bayoumi's house and 
Sharifa Salah el Dine finds her by the Nile, homeless and confused. Sherifa is a courtesan who doubles as a pimp. In the guise of protecting her from men and providing shelter, food and clothing for her, Sharifa introduces her to prostitution. She keeps Firdaus in her house and brings men who sleep with her in exchange for money; the money is paid to Sherifa, not Firdaus. She prostitutes and exploits young women like Firdaus, but she is also exploited by some men and pimps who rape her, beat her up and take away her money. For example, Fawzy beats, rapes and controls her; she depends on Shawki for protection. Indeed, men control the sex industry.

Once again, Firdaus escapes and becomes a "free"and "successful” prostitute. Her sense of freedom and success seems to be affected by Saadawi's(1980) definition of prostitution. According to her, "Prostitution means sexual intercourse between a man and a woman aimed at satisfying the man's sexual and the woman's economic needs" (p. 56). This definition appears adequate, but it does not recognize the fact that men also control the money women make from prostitution, that men force women into prostitution and control their earnings.

Firdaus's belief that a prostitute has more value, is more respected, and is wiser than other women; that a prostitute is completely independent, free from subjection to a man, marriage or love is an illusion, a negative argument born of anger against men and patriarchal society. She tries to console herself with the following ideas: "A successful prostitute was better than a misled saint," "the least deluded of all women was the prostitute. That marriage was the system built on the most cruel suffering for women" (p. 94), "a woman's life is always miserable. A prostitute, however, is a little better off" (p. 97).

Deluded by frustration and anger, Firdaus luxuriates in perverse logic and fatalism. She sees prostitution as a revolt against patriarchal subjugation and double standards. She sees herself as enjoying some freedom not accessible to other women. She sees herself as "a very successful prostitute" (p. 97). But her success attracts a different kind of client that really questions her claim to complete freedom and gives her a rude awakening. When a foreign politician declares interest in her and sends for her and she turns him down, policemen are sent after her to either persuade her or force her into sleeping with the politician. One of the policemen tell her that "refusing a Head of State could be looked upon as an insult to a great man and lead to strained relations between the two countries" (p. 98). Men control politics and use prostitutes as part of political, diplomatic tools or hospitality package. "On one occasion they put me in prison because I turned down one of these important men" (p. 99). She takes the case to court and wins after spending "a very big sum of money" (p. 99). But then she is disillusioned: she realizes that men control the sex industry and that whatever freedom she enjoys is what she is allowed to enjoy.

I knew that my profession had been invented by men, and that men had been in control of both our worlds, the one on earth, and the one in heaven. That men force women to sell their bodies at a price, and the lowest is that of a wife. All women are prostitutes of one kind or another. Because I was intelligent I preferred to be a free prostitute, rather than an enslaved wife (p. 99).

To operate as a prostitute in a society where prostitution is illegal, she bribes the police, and in times of trouble she also pays them for protection. But when she meets the pimp named Marzouk, she realizes that prostitution is an industry controlled by fundamental power structures, and operated by cartels and syndicates. She wants to buy him off as she buys the police but he refuses, he insists on sharing in her earnings, he wants to own her body and control her money. The following dialogue is quite revealing:

'Every prostitute has a pimp to protect her from other pimps and the police. That's what I'm going to do.”

'But I can protect myself,' I said.

“There isn't a woman on earth who can protect herself” (p. 100)

Prostitution involves power contestation. Pimps derive not just sexual pleasure and economic success from controlling prostitutes and exercising authority over them, it is also a source of power. As Haralambos and Holborn (2008) put it, "On the streets, pimping is one way to express masculinity. Pimps usually exercise strong control over the prostitutes they 'run'”(p. 382).So once again she seeks protection: first she goes to the police and then takes recourse to legal proceedings only to discover that Marzouk has more connections and influence in the society than she does, and also knows how to manipulate institutions to his advantage. Not even her money can protect her from him. He tells her, "I'm in business. My capital is women's bodies” (p. 101). She surrenders and he shares in every money she earns. In fact, he confiscates the larger part of the money she makes for himself. He beats her up and often tries to rape her. She later discovers she is not the only prostitute controlled, exploited financially and harassed sexually, beaten physically and tortured psychologically by Marzouk. It is at this point that it dawns on Fridaus that her idea of being a free prostitute better than other women was nothing short of self delusion. Thus, she says:

I realized I was not nearly as free as I had hitherto imagined myself to be. I was nothing but a body 
machine working day and night so that a number of men belonging to different professions could become immensely rich at my expense. I was no longer even mistress of the house for which I had paid with my efforts and sweat (103).

With this new awareness, Firdaus decides to quit prostitution, take her academic credentials and look for a job, but her pimp says she has no right to choose the type of work to do, saying as a prostitute she is a slave who has forfeited her freedom, integrity and honour to him. He tries to subdue her by beating her but she fights back. And when he goes for a knife in his pocket, she first grabs it and stabs him several times until he dies. Then she is condemned to death, a sentence she does not appeal, believing she has triumphed over men, her oppressors.

In Adimora-Ezeigbo's (2008) Trafficked and Unigwe's (2009) On Black Sisters Street, we see another dimension of prostitution: female trafficking and prostitution at international and transcontinental levels. The novelists expose various means through which sex syndicates deceive innocent young women, traffick them to European cities where they sell them or coerce them into prostitution for many years under very risky and dehumanizing circumstances. Like Saadawi, Adimora-Ezeigbo and Unigwe demonstrate that the quest for economic freedom and the attainment of the power that goes with it lure women into prostitution, willingly or unwillingly; and that in prostitution money and power are constantly at the centre of contestation and conflict, especially between men (as customers, pimps, traffickers, or brothel operators) and women (either as prostitutes or sex industry operators).

In Adimora-Ezeigbo's (2008) Trafficked, the heroine Nneoma and her friend Efe are lured into prostitution when they are about nineteen.The novelist exposes how deceptive, well organized the traffickers are. Efe is ensnared through a newspaper advertisement which invites young job seekers interested in working abroad to apply. This is an irresistible bait for youths desperate to escape the grinding poverty occasioned by mass unemployment and lack of basic amenities which make life meaningful. This is particularly during the military junta when corruption, administrative ineptitude, insensitivity, impurity and all forms of political and human rights abuses are the order of the day. Although young men and women are invited to this interview only ten applicants are selected, and all of them are girls. These girls are made to take an oath to work for the "agency" until they pay off all the money it spent to get them their international passports and tickets. These girls are trafficked to Italy where they are sold to waiting buyers in the sex slave market. There is a well organized underground sex slave market where young women are bought and sold as chattel.

Nneoma attended a teachers' training college. But she is jobless, and when her relationship with her fiancé is in crisis she becomes desperate to leave the village. Consequently, when her classmate and friend tells her that an agency had helped her secure a teaching appointment in the United Kingdom, she flees the village without telling her family her whereabouts. Her friend takes her to her sponsors in Lagos, and within a short time, she and five other young women between the ages of seventeen and twenty have their international passports, tickets and appointment letters ready, even though they turn out to be fake. It is imperative to note that traffickers have agents in embassies, airports, immigrations, the police and other institutions of governance through whom they facilitate and execute their nefarious activities all over the world. With their money and power, they render the law impotent.

These girls are made to take an oath that binds them to the agency until they pay their debt to the agency. They are later trafficked to Italy and turned into sex slaves instead of the UK where they are promised teaching jobs. Ezeigbo shows the links in the international sex trade. The trafficking agency has partners who operate in different countries. Nneoma narrates her ordeal thus:

In Italy I discover I am trafficked. I have no say in the matter. There’s a woman called Madam Dollar nothing comes between her and money. She owns us and the man, whom we learn to call captain, is her body guard. She keeps us prisoner in her flat. Life is hell in Rome - we are always walking the night, selling sex to Italian men and foreigners. I hate Madam Dollar. As soon as we arrive, she sells my friend. I have not set eyes on her since (p. 129).

These young women are forced to hit the streets at night even in the coldest winter nights. Whenever Nneoma does not bring back a lot of money, she is assaulted by captain. And whenever she fails to satisfy the demands of difficult customers like insisting that they use condom or avoid making love in certain positions, she gets beaten up and battered and thrown out of a car. The novelist portrays the terrible experiences of sex slaves, their dehumanization and shame, the emotional, mental crises and psychological trauma. Like Nneoma, they dream of escape and freedom, but they are alone, lost, vulnerable and helpless - mainly because they are illegal immigrants without valid documents or any documents at all.

Nneoma slaves for Madam Dollar for three years before she is sold to Baron who smuggles her and two other girls 
into London. Her experiences in London further capture the horrors of prostitution, particularly for trafficked women who practice prostitution without license. According to her:

Baron sends the other girls to brothels and keeps me in his flat. Instead of putting me on the street, he brings men to the flat. Baron is a sadist. He rapes and beats me. I refuse when customers demand oral or anal sex and insist that they use condoms and I'm sometimes assaulted for this. Baron locks me up in the flat, and does not allow me to go out except when he takes me with him (p. 132).

This is not surprising. Illegal prostitution, like drug trafficking, is a major component of the underground economy and so it inevitably involves violence in forms of rape and exploitation. The underground economy, also known as informal economy, “consists of economic activities - whether legal or illegal - that people don't report to the government" (Henslin 2010, p. 420). Even among licensed prostitutes in countries where prostitution is legalized and government protects them, violence and exploitation are constant threats. Dworkin (1995) asserts that:

The relationship of prostitution to rape is simple and direct: whatever can be stolen can be sold. This means that women were both stolen and sold; and when practices were codified into laws, women were defined as sexual chattel. Women are still basically viewed as sexual chattel socially, legally, culturally, and inpractice (p. 239).

In the three novels under study, so many women are raped, even outside prostitution. In On Black Sisters Street, at fifteen, Joyce is viciously gang-raped by the soldiers who kill her parents and her brother. Soldiers, in fact, abduct girls and use them as sex slaves (p. 168).

Nneoma is not given any money by either Madam Dollar or Baron, they take even the extra money some generous customers give her. Nneoma later escapes from Baron and is afterwards assisted by some sympathetic Nigerians in London until she is arrested and deported back to Nigeria.

Similarly, Efe is trafficked from Nigeria to Italy where she is sold to Madam Gold, a Nigerian sex industry proprietor. Like a cruel slave driver, she viciously compels the girls to walk the streets every night hawking their bodies. After four years of grueling sex slavery, Madam Gold sells Efe to a white pimp who exploits her for two more years before she escapes to Verona where she works as a free prostitute for one year before she is arrested and later deported.

Alice, one of the girls trafficked to Italy who was deported to Nigeria and kept at Oasis, a non-governmental organization that provides support for rescued or deported prostitutes, for rehabilitation is a graduate. She says if she had a job she would not have been trafficked and unashamedly states that if she does not find a job in Nigeria she would return to Italy. She prefers sex slavery in Italy to unemployment and poverty in Nigeria.

Ezeigbo (2008) also captures the stigmatization of former prostitutes (including rescued and rehabilitated sex slaves) and calls for public sympathy that could facilitate their integration into society. She demonstrates that prostitution is a huge industry with well organized underground global networks. For instance, Baron who buys Nneoma in Italy, smuggles her and some other girls to London where he has links with some brothels and clientele. After the girls are deported back to Nigeria, Nneoma and Efe discover that Baron is in Nigeria recruiting and trafficking young girls. But for Nneoma, Efe would have fallen prey again to Baron who now parades himself as Fyneface. Ezeigbo (2008) therefore draws attention to "the trafficking industry in Nigeria"(p. 135) which seems to run unchecked.

Chika Unigwe is a Nigerian writer based in Belgium. Her novel, On Black Sisters Street (2009), won the most prestigious literature prize in Africa, the NLNG Prize, in 2012. In an interview with Edozie Udeme, Unigwe (2013) identifies human trafficking as a major thematic preoccupation of the novel. According to her, "There are indeed Nigerian women in Antwerp, Belgium, working as prostitutes. There are lots and lots of them. For me, that is a story waiting to be written, waiting to be attended to. It was a story I knew I'd explore and the only way to explore it was for one to write about it. The core issues raised in that novel are all part of what we live with every day" (The Nation, p. 51). She describes the characters in the novel as authentic, pointing out that the novel is a product of her research on the involvement of Africans in prostitution in Belgium. She tells Adeola Ogunrinde, "I had to create characters which are real so I had to go to the Red Light District to speak to the prostitutes” (Sunday Sun, p. 26).

Like Adimora-Ezeigbo's Trafficked, Unigwe's (2009) On Black Sisters Street has trafficking and the international sex trade as its thematic thrust. Incidentally, Ifeanyi Ajaebo's Sarah House which was shortlisted for the NLNG Prize in 2012 also has trafficking and international sex trade as its controlling theme. Apart from prostitution, what Trafficked, On Black Sisters Street and Sarah House have in common is the diasporic experiences of Africans. In other words, these novels explore one aspect of the relationship between Africa and the outside world in the twenty-first century. This is reminiscent of Nnolim's (2006) charge to African writers: 
The African writer in the $21^{\text {st }}$ century should forget the complexes of the past and be more imaginatively aggressive and expansive, invading other continents and even the skies as new settings, striving to have a global outlook in his creative output, mounting a new international phase and not limiting his canvas to the African soil (p. 4).

These novels unfortunately paint disturbing pictures and raise poignant questions about the place of Africa in the twenty-first century globalized world. They remind us of Africa's victimhood in the trans-Atlantic slave trade of the seventeenth and eighteenth centuries, the cruel exploitation and dehumanization of colonialism in the nineteenth and twentieth centuries, and the despicable human trafficking and prostitution of African women in the twentieth century.

On Black Sisters Street is the story of four African girls who are trafficked to Europe and turned into sex slaves. Sisi, Efe and Ama are Nigerians while Joyce is a Sudanese girl also trafficked from Nigeria. These young women are trafficked to Antwerp, Belgium, by Senghor Dele, the owner of Dele and Sons Limited: Import-Export Specialists, a company that exports girls to Europe where they are turned into sex slaves. As Dele proudly tells Sisi, "Every month I send gals to Europe. Antwerp. Milan. Madrid. My gals dey there. Every month four gals.Sometimes five or more" (p. 39). Unigwe (2009) explores how failed leadership and harsh economic conditions turn desperate young women into easy preys for wicked women traffickers and other operators of the sex industry. She depicts in a compelling narrative how prostitution destroys the dreams, aspirations and destinies instead of giving them economic freedom and power that they expect. Sisi is a young graduate who once dreamed of becoming a successful banker and important member of society with money and power to affect the lives of her family and command respect in society. Joyce allows herself to be trafficked believing she is going to Belgium to do nanny work and make some money. Before her parents were brutally murdered by Sudanese soldiers who sacked her community, she once aspired to become a medical doctor. Efe wanted to be a writer; Ama, a graduate. Sadly, prostitution ruins these dreams as well as the dreamers.

Upon their arrival in Antwerp their passports are confiscated by Madam who runs Dele's prostitution business there and they are tricked into going to the Ministry of Foreign Affairs, using fake names and no documents, to register as asylum seekers. It appears that Madam has people in her pay role in the ministry who ensure that the girls are not granted asylum but ordered to leave the country within few days. That way they are persona non grata illegal aliens, voiceless, vulnerable and susceptible to exploitation. In the case of the protagonist, Sisi, having confiscated her passport and the paper that declares her persona non grata and gives her three days to leave the country, Madam tells her, "Now you belong to me," (p. 156) adding that until she pays up all the money that was invested on her she would not have her passport back.

Every month we expect five hundred euros from you. That should be easy to do if you are dedicated. But I understand that sometimes you may not be able to, so we have set a minimum repayment of one hundred euros. Every month you go to the Western Union and transfer the money to Dele (pp. 156-157).

It is important to note that though Madam is the boss of the four prostitutes in Antwerp, the girls make their payments directly to Dele in Nigeria through Western Union money transfer. The girls are commodified and made "to stand in front of the glass showcase, strutting in sexy lingerie, lacy bras and racy thongs to attract customers" (p. 152). In fact, Madam's description of Villa Tinto, one the brothels in the red light district of Antwerp vividly capture how prostitution reduces women to commercial goods and the institutions involved in it:

Villa Tinto.The queen of all brothels. Even has its own police station. It just opened a few months ago. January or February, I think it was. It used to be a warehouse before it was converted. Cost a lot for the conversion. It had to. It's a paradise inside, all high-tech. Designed by some celebrity architect. I hear the girls who work inside have panic buttons beside their beds to press when a customer gets out of hand. They have Jacuzzis.Saunas.That kind of stuff.Too costly for us. Not too many black women inside. Two, three, tops. This is where ministers get their girls. The girls here are top class (pp. 174-175).

The conversion of a warehouse to a brothel is the novelist's way of making a strong, symbolic statement about the objectification and commodification of women. The obscene and ungodly display of women in glass showcases like fried chicken or hamburger or dress is not a figment of the novelist's imagination. It is based on fact. Most cities of the world today have their red light districts (sex markets or shopping malls). One of such cities is Amsterdam, and according to Henslin (2010), p. 293), "the state licenses the women and men, requiring that they have medical checkups (certificates must be posted); and the prostitutes add sales tax to the receipt they give customers. The prostitutes sit behind lighted picture windows while customers stroll along the narrow canal side streets and browse 
from the outside."

Sisi's first night as a prostitute is at a dirty café where black girls are used in filthy toilets. Prostitutes are generally regarded as fallen women, but being used in dirty toilets of a café is the novelist's way of symbolically projecting the degree to which prostitution can dehumanize humans. She is later upgraded to a brothel where she is displayed in a glass showcase. Yet the novelist shows that the quest for economic power is a primary attraction to prostitution: some people forget about their dignity and pride. For instance, when Dele proposes to take Ama to Europe for prostitution, she feels insulted and is so angry that, to protect her honour, she spits on him and walks out on him. But desperate to escape a terrible past, the present hopelessness of her economic situation, and a bleak future, she later returns to Dele and begs to be trafficked. He feigns anger initially and later tells her he has forgiven her. Dele tells her in a language that effectively reflects the way some men see women, "You get life! Plenty fire for your voice. Any man wey get you na real pepper soup him get, I swear" (p. 141). "I shall sample you before you go" (p. 142). Because of Ama's economic desperation, she does not mind being called and treated or sampled as a man's pepper soup. Yet as a prostitute she does not keep the money she makes for more than eight years; she labours for Dele and Madam.

Sisi works for nine months during which she realizes that the pain of the knowledge that she is being fleeced is more unbearable than the pain and shame of the slavery itself. "When business was good, Sisi did an average of fifteen men" (p. 223).She is tortured that after all the risk and debasing labour, somebody else takes the money, the fruit of her sweat. Consequently, encouraged by her Belgian boyfriend, Luc, who promises to protect her from Madam and Dele, she decides to escape. But she is murdered by Segun, Madam's (and ultimately) Dele's hit man. Unlike Nneoma and Efe in Trafficked, Sisi loses her life to the underworld of prostitution. Ironically, Dele has two daughters aged eleven and twelve of whom he says, "Any man wey mess with dem in future I go finish am. I go kill de man. I go squash am like ordinary mosquito. I swear” (p. 138).

\section{Conclusion}

In conclusion, Saadawi (2007), Adimora-Ezeigbo (2008) and Unigwe (2009) demonstrate that if economic dependence and gender hierarchy give the woman a subordinate status and make her powerless, prostitution deteriorates that subordinate status and robs her of true dignity, social prestige and power.The novelists capture the dilemma of female prostitutes in the power game of trafficking and prostitution. Women who are forced into prostitution and those who willingly go into illegal prostitution are simply sex slaves, enriching others, especially men who control the sex industry as corporate business or underground syndicate. Instead of the attainment of agency, subjectivity, and power, prostitution subjects women engaged in it to the worst forms of dehumanization, exploitation, violence and victimhood. Prostitution has grave consequences for women: sexual violence in form of physical abuse or rape, dehumanization, economic exploitation, slavery, and death.

The novelists also make important political statements that clearly suggest that the failure of African leaders to empower and improve the lives of their people, that as corruption increases exponentially and the poor are confined to a vicious cycle of poverty, the crime of trafficking and prostitution inevitably flourishes. In the words of Uko (2006), "Prostitution constitutes an affront to the post colonial/contemporary leadership in Africa, and the nature of the post colonial/contemporary leadership in Africa is a mockery of modern civilization in global contexts. From the reality that confronts women, it is clear that the pursuits and goals of African leaders are puerile and their vision which is largely demented often times combine to drive women to the incongruous" (p. 152). These novelists have not set out to perpetuate the negative image of women, a charge that has been leveled against most male African writers. Rather, they recreate reality as photographically, and credibly as possible in order to challenge assumptions such as bottom power being ultimate power, and prostitution being an easy route to female independence, economic freedom and socio-political power and prestige. They do not justify prostitution, rather they present it as a menace, a national or continental tragedy that must be tackled urgently.

\section{References}

Adimora-Ezeigbo, A. (2008).Trafficked. Lagos: Lantern Books.

Chinweizu. (1990). Anatomy of female power. Lagos: Pero Press.

Diop, C. A. (1987). Black Africa: The economic and cultural basis for a federated state. Trenton: Lawrence.

Dworkin, A. (1995). Pornography and male supremacy. Gender, race and class in media: A text reader. Ed. Gail 
Dines \& Jean M. Humez.London: SAGE Publications.

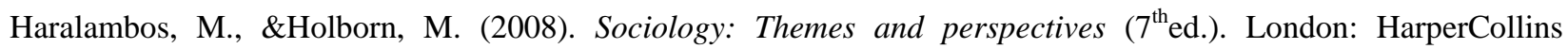
Publishers.

Henslin, J. M. (2010). Sociology: A Down-to-Earth Approach. Boston: Pearsons.

Huda, S. (2006, February). 'Report of the Special Rapporteur on the human rights aspects of the victims of trafficking in person, especially women and children, Sigma Huda' for the United Nations Commission on Human Rights. Retrieved from http://www.en.wikipedia/feminismviews-on-prostitution

Nnolim, C. E. (2006).African literature in the $21^{\text {st }}$ century: Challenges for writers and critics. New direction in African literature (25. Ed.), Ernest N. Emenyonu. 1-9.

Uko, I. I. (2006, May). Female prostitution as metaphor for survival in Cyprian Ekwensi’s Jagua Nana and Nawal El Saadawi's Woman at point zero. Currents in African literature and the English language, 4, 142-154.

Unigwe, C. (2009). On Black sisters street. New York: Random House.

Unigwe, C. (2013). I always wanted to be a writer - Chika Unigwe, winner of the NLNG's Nigerian literature prize, 2012. Sunday sun. August 25: 26.

Unigwe, C. (2013). Prostitution is big business in Belgium. The nation on Sunday. February 10: 51.

Saadawi, E. N. (1980). The hidden face of eve. London: Zed Books.

Saadawi, E. N. (2007). Woman at point zero. London: Zed Books.

The four pillars of Mut'a-Al-Islam (2013, September). Retrieved fromwww.al-islam.org/al-serat/muta/3.htm 